\title{
THE EFFECT OF KOREAN BOBATH EXERCISE ON BRAIN DERIVED NEUROTROPHIC FACTOR AND MOTORIC MOVEMENT QUALITY IN CHILDREN WITH CEREBRAL PALSY
}

\author{
Siswarni' ${ }^{\text {, }}$, Harsono Salimo'), Angela BM Tulaar3), Suroto4) \\ 1)Doctoral Program in Medicine, Universitas Sebelas Maret \\ 2)Department of Pediatric, Faculty of Medicine, Universitas Sebelas Maret \\ 3)Department of Physical Medicine and Rehabilitation, \\ Faculty of Medicine,Universitas Indonesia \\ 4)Department of Neurology, Faculty of Medicine,Universitas Sebelas Maret
}

\begin{abstract}
Background: In cerebral palsy (CP), there is damage to the cerebral cortex. The Korean Bobath Exercise (KBE) is based on brain plasticity theory. As a method of learning it may result in a better quality of motoric movement. This study aimed to examine the effect of $\mathrm{KBE}$ on change of brain derived neurotrophic factor (BDNF) and motoric movement quality in CP.

Subjects and Method: This was a randomized controlled trial conducted at Yayasan Pembinaan Anak Cacat (YPAC) and Prof. Dr. R. Soeharso Orthopedics Hospital, Surakarta, Central Java, from October 2017 to February 2018. A sample of 34 children aged 2 to 7 years with $\mathrm{CP}$ was selected for this study. This sample was allocated at random into the $\mathrm{KBE}$ group $(\mathrm{n} 1=17)$ and the control group (n2=17). The dependent variable were BDNF and motoric movement quality. The independent variable was Korean Bobath Exercise. Pre and post peripheral BDNF exercise was measured in 8 weeks by ELISA blood test. Motoric development quality was measured by levelization. KBE was measured by scoring. The changes in BDNF before and after intervention between the KBE group and the control group were tested by t-test. The changes in motoric movement quality before and after intervention between the KBE group and the control group were tested by Chi-Square.

Results: Before and after intervention, the increase of BDNF in the KBE group (mean $=5.97 ; \mathrm{SD}=5.08$ ) was higher than the control group (mean $=3.43, \mathrm{SD}=$ 2.64) with $\mathrm{p}=0.231$, indicating that the $\mathrm{KBE}$ was not effective to increase BDNF. Before and after intervention, the increase of motoric movement quality in the KBE group (100\%) was higher than the control group (57\%) with $\mathrm{p}=0.008$, indicating the KBE was effective to increase motoric movement quality.

Conclusion: Data from the current study does not provide evidence thatKorean Bobath Exercise is effective in increasing brain derived neurotrophic factor. However, the current study gives evidence that Korean Bobath Exercise it is effective in improving motoric movement quality in children with cerebral palsy.
\end{abstract}

Keywords: Korean Bobath Exercise, brain derived neurotrophic factor, cerebral palsy

\section{Correspondence:}

Siswarni. Doctoral Program in Medicine, Universitas Sebelas Maret, Jl. Ir. Sutami No. 36 A, 57126, Surakarta, Central Java. Email: meniksis@ymail.com.

Mobile:081329045530

Mid-International Conference on Public Health, Best Western Premier Hotel, Solo, Indonesia, 18-19 April 2018 | 264 https://doi.org/10.26911/mid.icph.2018.05.25 